\title{
Long-lasting consequences of war on disability in Vietnam
}

\author{
Michael Palmer ${ }^{1}$, Cuong Nguyen ${ }^{2}$, Sophie Mitra ${ }^{3}$, Daniel Mont ${ }^{4}$, Nora Groce ${ }^{4}$ \\ ${ }^{1}$ Department of Economics, The University of Western Australia, 35 Stirling Hwy, Perth WA, 6009, Australia. \\ Email: michael.palmer@uwa.edu.au (corresponding author) \\ 2 Institute of Public Policy and Management, National Economics University, Tran Dai Nghia Street, Hanoi, \\ Vietnam. Email: cuongwur@gmail.com \\ ${ }^{3}$ Department of Economics, Fordham University, 441 E Fordham Rd, Bronx, NY 10458, United States. Email: \\ mitra@fordham.edu \\ ${ }^{4}$ UCL Disability Research Centre, Department of Epidemiology and Public Health, University College London, \\ 1-19 Torrington Place, London, WC1E 6BT, United Kingdom. Email: danielmont01@gmail.com, \\ nora.groce@ucl.ac.uk
}

\section{Acknowledgements}

We gratefully acknowledge comments from the editor Gudrun Østby and three anonymous reviewers, Dennis Petrie, participants of the IRDES-Dauphine Workshop on Applied Health Economics and Policy Evaluation (Paris, France), the GREThA International Conference on Economic Development (Bordeaux, France), and the Australian Health Economics Society Conference (Hobart, Australia).

Word count: 8998 including abstract, text, references, bio statements, acknowledgments, tables and figures (excluding appendices) 


\begin{abstract}
This article investigates the impact of exposure to United States (US) air force bombing during 1965-1975 on the disability status of individuals in Vietnam in 2009. Using a combination of national census and US military data and an instrumental variable strategy which exploits the distance to the former North-South border as a quasi-experiment, the article finds a positive and significant impact of bombing exposure on district level disability rates forty years after the war. The overall effect of bombing on the long-term disability rate among the Vietnamese population is highest among heavily bombed districts. Districts in the top bombing quintile experience a $25 \%$ relative increase in the rate of disability attributable to bombing compared with districts in the lowest bombing quintile. Effects are highest on the prevalence of severe disability and among cohorts before the war's end. A smaller, yet significant, effect is found among cohorts born after the war. Findings suggest indirect channels through which bombing impacted on long-term disability in Vietnam are adverse effects on nutritional environment and human capital attainment. These findings from Vietnam underpin the importance of expediating the process of cleaning up the consequences of war, and in ensuring food security and adequate health and rehabilitation services for people in conflict-affected zones.
\end{abstract}

\title{
Introduction
}

Wars and armed conflicts are detrimental to the development of nations. Whilst wars between states today are far less common than they were in the past, and civil wars are 
declining in number, the effects of past conflicts on exposed populations can last for many decades after the conflicts have ceased (Minoiu \& Shemyakina, 2014; World Bank, 2011). This may be particularly the case for human capital accumulation, and health in particular. Attention is often focused on the death toll of war, especially in the short run, but war also has long lasting impacts on the health of survivors and of people born after war ends. Wars inflict injury and trauma through direct exposure to violence and weapons. However, the indirect or 'hidden' effects of war on health may also be substantial and not surface until generations later (Ghobarah, Huth \& Russert, 2003; Ugalde, Richards \& Zwi, 1999). This may occur, for example, through the destruction or depletion of health care infrastructure and services; the reduction of arable land and nutrition; disruption to education and livelihoods; and contamination of the environment. Empirical evidence on the extent to which conflict impacts the long-term health of exposed populations, and in particular the channels through which this occurs, however is limited and has important implications for the development of policies to stem the consequences of conflict.

Economic growth theory predicts that war should have only temporary effects on the economy (Miguel \& Roland, 2011). A transitory increase in capital accumulation and growth in war-affected areas is predicted until the steady state is reached. Macro-level studies in Japan, Germany and Vietnam show that countries return to their steady state after 20-25 years (Brakman, Garretsen \& Schramm, 2004; Davis \& Weinstein, 2002; Miguel \& Roland, 2011). ${ }^{1}$ Similar post-war recovery patterns are predicted for human capital,

\footnotetext{
${ }^{1}$ The studies find no persistent impact of bombing on indicators such as city size, population density, physical infrastructure and poverty.
} 
including health. The effects of warfare on health may be overcome in the long-term by post-war investments in public health care and other infrastructure, as well as via accumulation of human capital through investment in health inputs and behaviors (Strauss $\&$ Thomas, 2008). However, there are multiple hypotheses on why the health effects of war may be pervasive. For instance, wars place pressures on public resources towards economic and military reconstruction rather than the rebuilding of health systems; exposure to biological and chemical agents of warfare can cause delayed and inter-generational health effects; poor conditions experienced during pregnancy and early childhood may have irreversible consequences for health (Barker, 1992; Ghobarah, Huth \& Russert, 2003; Ugalde, Richards \& Zwi, 1999).

Both a civil and interstate conflict involving a variety of actors over time, it is difficult to characterize the war in Vietnam. The most intense period was marked by the military intervention of the United States (US) and allied forces over the period 1964-75. The cornerstone of the US military strategy was an extensive bombing campaign, described as the most intense aerial bombing episode in history (Dell \& Querubin, 2018; Kocher, Pepinsky \& Kalyvas, 2011). Over six million tons of bombs and other ordinance were dropped in the Indochina region at a weight four times greater than in Germany during World War II (Clodfelter, 1995). The loss of Vietnamese lives during the 'American war' period was immense, with estimates ranging from 1-2 million (Hirschman, Preston \& Vu, 1995; Obermeyer, Murray \& Gakidou, 2008). Millions more were thought to be wounded (Kalyvas \& Kocher, 2009). However, the long-term impacts of the war on the health of the Vietnamese population remain only partially documented. This question is particularly 
salient for Vietnam as Miguel \& Roland (2011) found no significant long-term impact of US bombing on local poverty rates and other measures of economic development in Vietnam. Has Vietnam also overcome non-economic effects of the conflict with respect to health?

This article answers this question by estimating the impact of US bombing over the period 1965-1975 on disability prevalence in Vietnam four decades later. Drawing upon a combination of national census and US air force data and an estimation strategy which instruments geographical bombing exposure with distance from the $17^{\text {th }}$ parallel demilitarized zone, this article shows a significant link between wartime bombing and district level disability prevalence approximately forty years after the war. Highest effects are observed for severe disability and for persons aged around 40 years who were born in the years experiencing the highest density of bombing. Taken together with the work of Miguel \& Roland (2011), our findings suggest that wars inflict external costs on the health of human populations that last longer than those relating to economic growth and welfare.

This article makes several noteworthy contributions. First, we contribute to the determinants of disability literature. Approximately 15\% of the world's population, more than a billion people, are estimated to be living with a disability (World Health Organization \& World Bank, 2011). According to contemporary international classification, disability is understood as a dynamic interaction between health conditions and contextual factors, both personal and environmental (World Health Organization, 2001). For some environmental factors, such as those associated with malnutrition and 
poverty, the impact on health conditions associated with disability is well established (World Health Organization \& World Bank, 2011). Major environmental changes, such as those caused by natural disasters or armed conflict, and their links to disability are less understood. Ghoboarah et al. (2003) estimate the long-term effects of civil war on disability. However, the measure of disability - disability-adjusted life years (DALYs) - is controversial and the methods of analysis do not address the non-random nature of warfare exposure. ${ }^{2}$ In this article we adopt a measure of disability consistent with the International Classification of Functioning, Disability and Health of the World Health Organization and a methodology which enables us to address unobserved heterogeneity.

Second, we contribute to the international evidence on the long-lasting effects of war on health. In line with Barker's (1992) hypothesis linking early childhood environment and health outcomes later in life, most of this literature focuses on effects among affected children. Exposure to armed conflict in utero or in early childhood or adolescent years is associated with substantially lower height or height-for-age scores (a proxy for long-run nutritional status and health) in later life in multiple contexts (Akresh, Lucchetti \& Thirumurthy, 2012; Bundervoet, Verwimp \& Akresh, 2009; Grimard \& Laszlo, 2014; Minoiu \& Shemyakina, 2014). Exposure to armed conflict in childhood has also been linked to long-lasting detrimental effects on mental health, self-rated health satisfaction, BMI, and chronic health conditions such as stroke, hypertension, diabetes, and

\footnotetext{
${ }^{2}$ DALYs are argued to be inconsistent with contemporary international classification of disability and are constructed from disease and impairment data which may be highly subject to measurement error in lowresource settings (Mont, 2007).
} 
cardiovascular disease (Akbulut-Yuksel, 2017; Akbulut-Yuksel, 2014; Singhal, forthcoming).

This article adds to this literature by quantifying the long-term effects of conflict on disability. Specifically, we use a measure of disability developed by the UN Washington Group on Disability Statistics, known as the Washington Group Short-Set Questionnaire. ${ }^{3}$ The measure does not identify particular health conditions or impairments but instead captures the impact of a combination of factors (health included) on basic functional abilities (Madans, Loeb \& Altman, 2010; Madans, Loeb \& Eide, 2017). As such, the measure may be less susceptible to measurement error associated with other chronic health and disability measures. We estimate effects across the all-age population as well as heterogenous effects by birth cohort to provide a more complete picture of the population health effects of bombing.

Third, we contribute to the literature on the health effects of the 1965-75 conflict on the Vietnamese population. Most studies find that the war in Vietnam had a negative effect on health using a wide range of indicators for adults, functional and mental functioning (Singhal, forthcoming; Teerawichitchainan \& Korinek, 2012), and for children, congenital impairments (Le et al., 1990), mortality (Hirschman, Preston \& Vu, 1995; Savitz et al., 1993), infant neurodevelopment (Pham et al., 2013) ${ }^{4}$ Closest to our article is a study that

\footnotetext{
${ }^{3}$ http://www.washingtongroup-disability.com.

${ }^{4}$ A few studies do not offer evidence that the war negatively affected health outcomes in Vietnam (Do, 2009;

Teerawichitchainan \& Korinek, 2012).
} 
estimates the long-term effects of bombing on mental health outcomes (Singhal, forthcoming). Using the 2016 wave of the Vietnam Access to Resources Survey and the same IV identification strategy, Singhal (2018) finds a substantial effect of early-life exposure to bombing on the likelihood of severe mental stress in adulthood. The survey, and representativeness of results, is restricted to rural households in twelve provinces.

Our article also makes several contributions to the Vietnam literature. First, existing articles focus on subsamples of the Vietnam population that are not nationally representative. Second, this article is the first to use an internationally tested measure as an indicator for disability. Third, the vast majority of articles do not adopt an identification strategy to address unobserved heterogeneity. Drawing upon national census data, a standardized international health measure and an instrumental variable approach, we isolate the impact of the war on disability prevalence at the district level 40 years after the war. In addition, we add to understanding on the mechanisms through which the war impacted on the longterm health of the Vietnamese people through the compilation of public healthcare data and improved or updated household survey data.

\section{Conceptual framework}

To more formally build our hypothesis about the long-term impact of bombing on disability in Vietnam, we draw upon general conceptual frameworks linking exposure to conflict and long-term health (Ghobarah, Huth \& Russert, 2003; Ugalde, Richards \& Zwi, 1999). 
Broadly, conflict gives rise to a range of conditions that increase the risk of disease and injury whose longer term consequences are exacerbated by other macro-level influences of conflict on public health (Ghobarah, Huth \& Russert, 2003). ${ }^{5}$ Following Ugalde et al. (1999), we focus on several common conditions linking exposure to conflict and adverse consequences for health as relates to the war and disability in Vietnam.

The destruction and deterioration of healthcare infrastructure and services due to bombing could hasten the sequela of injuries and health conditions into long-term impairments and disability. Whilst no link could be found between bombing and depleted public healthcare provision during the active war period in Vietnam (Dell \& Querubin, 2017), economic difficulties and limited investments in public health infrastructure in the post-war period are well documented (Segall et al., 2002). Whilst the network of community health stations was extensive, resources were not made available in a timely fashion to meet health worker salaries and the provision of drugs (Ensor \& San, 1996). The resulting impact on the quality of services led to a series of health care reforms in the late 1980's. The introduction of user fees at public health facilities led to a decline in the use of formal health care and delays in treatment among the poor and rural population (Ensor \& San, 1996). Given that the majority of bombing was in rural areas, it is possible that health conditions acquired as a consequence of the war deteriorated into functional difficulties or their difficulties increased in degree. Alternatively, it is possible that more heavily bombed areas

\footnotetext{
${ }^{5}$ Macro-level influences can be summarized as: (i) reduced public and private resources to finance health care; (ii) other pressing competing demands for public expenditures in the aftermath of war; and (iii) reduced efficiency in the use of public health resources (Ghobarah, Huth \& Russert, 2003).
} 
experienced disproportionate levels of public infrastructure and health service investments in the post-war period such that the average long-term impact of bombing on disability has been reduced. Though not disaggregated by health, post-war state investments are positively correlated with bombing intensity (Miguel \& Roland, 2011). ${ }^{6}$ Through the compilation of detailed provincial level healthcare information on the number of hospitals, hospital beds and doctors, we assess the extent to which bombing impacted on the long-run provision of healthcare services.

Bombing may induce negative impacts on nutritional status which, in turn, leads to longterm health conditions and disability. The reduction in food availability in conflict situations is often accompanied by deficiencies in protein, calories and micronutrients which can cause severe malnutrition (Ugalde, Richards \& Zwi, 1999). Malnutrition and poor living conditions in the fetal stage and early childhood is associated with a range of physical and mental health conditions in later life (Almond \& Currie, 2011). ${ }^{7}$ It is estimated that $10 \%$ of sorties supported US allied troop ground operations and the remainder targeted enemy supply lines and insurgents (Dell \& Querubin, 2018; Thayer, 1975). Targeting of physical and transportation infrastructure reduces food distribution whereas extensive aerial bombing and unexploded ordinance reduces the availability of arable land for food production. Loss of harvest and business activities reduces household economic resources

\footnotetext{
${ }^{6}$ Over the period 1981-85, heavily bombed regions received 30\% more state investment in per capita terms relative to other regions (Miguel \& Roland, 2011).

${ }^{7}$ According to the 'thrifty phenotype hypothesis' metabolic systems adapt to the dire nutritional circumstances experienced in the pre- or early post-natal period which leaves individuals susceptible to obesity and chronic health conditions later in life (Barker, 1992).
} 
for health production. Indeed, Singhal (2018) finds that exposure to bombing in early childhood in Vietnam significantly reduced adult height-for-age (a strong proxy for socioeconomic conditions and nutrition in childhood) by 0.026 standard deviations or approximately $0.7 \mathrm{~cm}$. However, the sample upon which the Singhal (2018) study was carried out is limited in size and geographical representativeness. We examine long-run effects of bombing on adult height using the Vietnam National Health Survey, a large nationally representative sample with extensive sampling in the central region where the heaviest bombing took place.

Conditions of conflict pose a substantial threat to economic resources which may impact on disability through its impact on nutritional status or through any number of other mediums, such as educational attainment (World Health Organization \& World Bank, 2011). Miguel \& Roland (2011) find no significant long-run effect of bombing on poverty rates in Vietnam, consistent with the finding of Singhal (2018) on weight-for-age (a proxy for current socio-economic conditions). We examine the impact of bombing on poverty using updated household living standards and census data approximately 40 years after the war compared to Miguel \& Roland's (2011) estimates based on data reflecting impact 20-25 years after the war.

Access to education is an important and well-established input to health production over the life course which is commonly disrupted during violent conflict (Strauss \& Thomas, 2008). There exists a relatively large literature establishing a causal link between conflict and reduced human capital among exposed populations (e.g. Akbulut-Yuksel, 2014; Inchino \& 
Winter-Ebmer, 2004). In the context of Vietnam, Dell \& Querubin (2017) find that bombing reduced access to primary school education by 16 percentage points in hamlets during the war time. Miguel \& Roland (2011), however, find no long-term impact of bombing on literacy using 1999 census data. We add to this literature by estimating longer run impacts on an alternate human capital measure (years of schooling completed) in 2009.

Exposure to biological and chemical agents used in warfare is associated with delayed and intergenerational health effects (Ugalde, Richards \& Zwi, 1999). The conflict in Vietnam witnessed the first full-scale use of herbicides in warfare. ${ }^{8}$ Approximately two-thirds of the herbicides sprayed contained a highly toxic irremovable chemical, commonly known as dioxin, which is capable of concentrating in the body of animal and humans (Stellman et al., 2003). The US Institute of Medicine has concluded that a sufficient or suggestive link exists between exposure to dioxin contained in US military herbicides and a range of cancers and chronic health conditions, including Spina bifida in the offspring of exposed people (Institute of Medicine, 2014). Multiple studies have attempted to estimate the health effects associated with military herbicide exposure on the Vietnamese population (Do, 2009; Le et al., 1990; Le \& Johansson, 2001; Pham et al., 2013). For various reasons, some of which are mentioned above, the full extent of the population health effects are not known (Palmer, 2007). The primary purpose of the use of herbicides was as a defoliant to remove forest cover to the enemy but it also aimed to destroy 'unfriendly' food crops and supplies

\footnotetext{
${ }^{8}$ Over the period 1961-71, more than 70 million liters of herbicides were sprayed by the US and Republic of Vietnam forces upon an estimated 2.1 million people (and as many as 4.8 million) and 15-16\% of land cover of the former South Vietnam (Stellman et al., 2003).
} 
(Stellman et al., 2003). Therefore, it is possible that the health effects of the herbicides occur through direct exposure to the dioxin or through indirect effects associated with nutrition. Unfortunately, our dataset does not contain information on the level of herbicide spraying so we are unable to formally test this mechanism or control for it in regressions. However, to the extent that bombing is correlated with herbicide spraying, our bombing measure will capture the effects of herbicides. One of the primary purposes of the spraying operation was to make bombing targets more visible which suggests a degree of correlation (Stellman et al., 2003). Spraying maps resemble those of bombing maps with the highest levels of spraying taking place in the central province region surrounding the $17^{\text {th }}$ parallel demilitarized zone and in regions where the 'Ho Chi Minh Trail' entered South Vietnam (Stellman et al., 2003).

Our bombing measure will also pick up delayed health effects associated with unexploded ordnance (UXO) and landmines. It is estimated that $10 \%$ of ordnance did not detonate on impact (Tran, Le \& Husum, 2012). Due to the scale of the problem, the clearing of ordinance has been slow going with an estimated $19 \%$ of land still polluted by UXO and landmines (Tran, Le \& Husum, 2012; Tuoitre, 2018). ${ }^{9}$ There exists an obvious correlation between bombing and UXO, and US and allied troop movements were concentrated in the regions with the highest level of bombing which suggests a degree of correlation between bombing and the planting of landmines. To the extent that bombing is correlated with other weapons of warfare, our bombing measure is a proxy measure for overall war intensity and

\footnotetext{
${ }^{9}$ In Quang Tri province, which was subject to the heaviest bombing, it is estimated that one-half of all land is contaminated with over 100,000 tonnes of UXO and mines (Hoang, 2018; Tran, Le \& Husum, 2012).
} 
will pick up intergenerational effects on human health associated with these weapons. Our analysis extends to persons born before and after the cessation of bombing to capture the indirect effects associated with the above mechanisms as well as on-going exposure to weapons.

\section{Data and descriptive statistics}

\section{Data and variable definitions}

This study draws upon two unique data sets for the main analysis of war intensity on disability as well as several other data sources for the analysis of mechanisms. War intensity is proxied by bombing data obtained from a database assembled by US Defense Security Cooperation Agency. ${ }^{10}$ Specifically, our measure of bombing intensity is defined as the total number of bombs, missiles and rockets per $\mathrm{km}^{2}$ dropped by US and allied forces over the ten-year period, 1965-75 (hereafter bombs, missiles and rockets per $\mathrm{km}^{2}$ ). Bombs were the most common ordinance category and are highly correlated with other ordinance categories e.g. cannon artillery, ammunition (Miguel \& Roland, 2011). As previously discussed, bombing was central to the US Military strategy and is correlated with other weapons thus represents a suitable proxy for war intensity.

To measure disability prevalence at the district level, we use the $15 \%$ sample of the 2009 Vietnam Population \& Housing Census (VPHC). The sample is representative at the district

\footnotetext{
${ }^{10}$ The data is measured at the district level (585 districts) and matched with coordinates contained in the 1999 Vietnamese Population and Housing Census. Refer Miguel \& Roland (2011) for a detailed description of the data.
} 
level and contains approximately 3.7 million households and 14.2 million individuals. The survey contains a measure of disability developed by the United Nations' Washington City Group on Disability Statistics (WG hereafter) recommended for use in national censuses and household surveys known as the WG Short Set Questionnaire. ${ }^{11}$ The 2009 VPHC included four of the six functional difficulty questions of the recommended short set questionnaire: seeing, hearing, walking, and remembering. The four domains are considered the most essential in determining disability status from census data (Washington Group on Disability Statistics, 2017). This study defines persons with disabilities according to thresholds of functional difficulty as follows: (1) Persons with disability: persons experiencing difficulty of any degree (some difficulty, a lot of difficulty or unable to do) in at least one functional domain; (2) Persons with severe disability: persons experiencing a lot of difficulty or unable to do in at least one functional domain.

To analyze potential pathways from bombing to long-term impact on disability we draw upon several other data sources. We draw upon anthropometric height data contained in the 2001-02 Vietnam National Health Survey as a latent stock measure of health and marker for nutritional environment in childhood (Case \& Paxson, 2010; Strauss \& Thomas, 2008). We draw upon household consumption data contained in the 2010 Vietnam Household Living Standards Survey to construct measures of district level per capita consumption and poverty rates. Measures were computed using the small area estimation method with the

\footnotetext{
${ }^{11}$ The questions ask about difficulties in six domains: (a) seeing (even when wearing glasses), (b) hearing, (c) walking/climbing stairs, (d) concentrating or remembering things, (e) self-care and (f) communication. For each difficulty, individuals respond on a scale of 1 to 4 as follows: 1) no difficulty, 2) some difficulty, 3) a lot of difficulty and 4) unable to do (http://www.washingtongroup-disability.com).
} 
2009 VPHS, as described in Lanjouw et al. (2017). We draw upon data on average number of years of schooling completed (for persons aged 22 years and above) contained in the 2009 VPHS as a measure of human capital attainment. Finally, we use public health information contained in the 2009 Statistical Yearbook of Vietnam to construct measures on the number of hospitals, patient beds, and doctors at the provincial level.

\section{Descriptive statistics}

Table I presents the average percentage of people aged above five with disabilities in each of the four functional domains and overall at district level. The percentage of people with disability is around $6 \%$. The average rate of persons experiencing difficulty in seeing, hearing, walking and remembering at the district level is $5.1 \%, 3.2 \%, 3.8 \%$ and $3.6 \%$, respectively. The prevalence of severe disability is $1.5 \%$. For both the general and severe disability measure, prevalence rates are higher in districts with higher bombing density (Table I) and are significantly higher among persons born before versus after the war (Table II) e.g. on average $11.8 \%$ of the district population born before 1976 have a disability compared to $1.4 \%$ born since 1976 . Figure 1 graphs the log of the bomb density and the log of the disability rate of districts. The correlation between bomb density and severe disability is positive, whereas the correlation between bomb density and overall disability is negligible. Figure 2 illustrates significant heterogeneity in the density of bombing and disability prevalence across districts in Vietnam.

\section{[Table I]}

[Figure 1] 
[Table II]

[Figure 2]

\section{Empirical strategy}

To estimate the long-run impact of bombing on disability in Vietnam we start with simple ordinary least squares (OLS) regression where we assume that disability prevalence at the district level is a reduced-function of the density of bombs and other control variables as follows:

$$
\log \left(\operatorname{disability}_{i}\right)=\alpha+\log \left(\text { bomb }_{i}\right) \beta+X_{i} \theta+u_{i}
$$

where $\log \left(\right.$ disability $\left._{i}\right)$ is the $\log$ of the rate of disability prevalence in district $i$; $\log \left(\right.$ bomb $\left._{i}\right)$ is the $\log$ of bomb density in district $i$ which is measured by the total number of bombs, missiles, and rockets per $\mathrm{km}^{2}$ dropped by US and allied forces in the district over the period 1965-1975; $X_{i}$ is a vector of exogenous control variables; and $u_{i}$ denotes unobserved variables. ${ }^{12}$ Control variables include those that are not affected by the treatment variable of bomb density: district area and elevation, the share of urban population, district capital and Northern region dummy, and distance to the major cities Da Nang, Hanoi and Ho Chi Minh city (Angrist \& Pischke, 2008; Heckman, Lalonde \& Smith, 1999). Standard errors are clustered at both district and province level using a multilevel

\footnotetext{
${ }^{12}$ Results are robust to the non-logged disability outcome (available upon request).
} 
clustering technique to address within- and between-correlation of errors at both the district and provincial levels simultaneously (Cameron, Gelbach \& Miller, 2011).

Since the US bombing was not random, it can be correlated with omitted variables and as a result OLS estimators can be biased. A standard econometric method to correct this bias is through an instrumental variable approach (Angrist, Imbens \& Rubin, 1996). An instrument must be highly correlated with the bombing variable but not the error term $u_{i}$. We follow the approach of Miguel \& Roland (2011) and use the distance from the center of each district to the 17th parallel north latitude as an instrument of bombing density. The 17th parallel north latitude was set in 1954 as the border between the former northern and southern Vietnamese territories. Since this was a border, it was heavily bombed and targeted by different types of weapons. The first-stage is expressed as follows:

$$
\log \left(\text { bomb }_{i}\right)=\alpha+\log \left(\text { distance_17lat }_{i}\right) \beta+X_{i} \theta+\varepsilon_{i}
$$

where $\log \left(\right.$ distance_17lat $\left._{i}\right)$ is the $\log$ of the distance from the center of district $i$ to the 17 th parallel north latitude. An important point in the identification strategy is that the determination of the $17^{\text {th }}$ parallel was the product of negotiations between the US and Soviet Union in the context of the Cold War (Miguel \& Roland, 2011). To the extent that the border was determined by factors external to Vietnam (rather than local geographical or socioeconomic factors which may be jointly correlated with disability status) and is correlated with the intensity of bombing, proximity to the former north south border can be 
viewed as a natural experiment with which to estimate the impact of bombing on disability prevalence.

Our identification strategy nonetheless remains open to potential bias. One particular concern relates to migration. If migration patterns during or after the war are jointly correlated with distance to the former border and the prevalence of disability then our results are biased. Unfortunately, no reliable record of migration during or in the immediate post-war period exists. However, no statistical relationship was found between bombing and population growth over the active (1969-1973) and post (1985-2000) war periods (Dell \& Querubin, 2018; Miguel \& Roland, 2011). Bombing furthermore did not have a consistent effect on the proportion of people not born in their current village of residence in 1997-98 (Miguel \& Roland, 2011). The qualitative literature suggests that forced urbanization happened to a lesser extent than expected and that the vast majority of households remained or returned shortly after bombing (Appy, 2015; Tirman, 2011). Whilst we cannot rule out selective migration on the basis of disability status in heavily bombed regions, these findings suggest that any potential bias is small.

\section{Results}

We start with double-log OLS regressions of disability on bombing intensity. In all models, the coefficient of the bomb variable is positive and statistically significant at standard levels of significance (Tables III \& IV). The coefficients are higher in magnitude and level of 
significance for severe disability compared to overall disability. A $10 \%$ increase in bombing density leads to relative increases of $0.30 \%$ in severe disability prevalence and $0.15 \%$ in overall disability prevalence.

Since the OLS estimator could be biased, we primarily rely on the IV regression. The first stage regression shows a strong correlation between the instrument and bomb density (Table A.II). Districts further from the $17^{\text {th }}$ latitude are less likely to receive bombs, missiles, and rockets with a t-statistic equal to ten. ${ }^{13}$ Districts further away from major cities were more likely to be bombed though the effect is only mildly significant whereas those that are located in northern regions or are higher in altitude experienced less bombing. There is no robust correlation between the level of bombing and district size, district capital, and share of the urban population.

The IV estimates for the general disability measure show a highly significant effect of natural $\log$ of bomb density on the natural log of disability prevalence (Table V). A $10 \%$ increase in ordinance leads on average to a $0.61 \%$ relative increase in the overall proportion of people with disability. Similarly, if the ordinance dropped increases by $10 \%$ the proportion of people experiencing difficulty in seeing, in hearing, in walking and in remembering increase in relative terms by $0.50 \%, 0.52 \%, 0.52 \%$, and $0.80 \%$, respectively.

\footnotetext{
${ }^{13}$ The Cragg-Donald Wald F statistic and Kleibergen-Paap Wald F statistic are 226 and 101 respectively, which are high, indicating that the instrument is strong (Cragg \& Donald, 1993; Kleibergen \& Paap, 2006; Staiger \& Stock, 1997).
} 
As illustrated in Figure 2, there was considerable variation in bombing intensity across districts. To better gauge the magnitude of the effect across districts, we disaggregate districts in quintiles by means of logged bombing intensity. Districts in the top quintile have a bombing intensity that is $406 \%$ that of districts in the bottom quintile. This translates into a $25 \%$ (406 $\times 0.061)$ relative increase in the rate of disability attributable to bombing in a high- versus low-bombed district. Given a mean disability prevalence of $6.53 \%$ in top quintile districts, this infers a 1.31 absolute percentage point decrease in disability prevalence if heavily bombed districts experienced a bombing intensity similar to the least bombed districts. ${ }^{14}$

A $10 \%$ increase in ordinance leads to a $0.88 \%$ relative increase in the proportion of people with severe disability (Table VI). Using a similar calculation as above, bombing accounts for a $36 \%$ relative increase in the prevalence of severe disability in a high- versus lowbombed district, equating to a 0.44 percentage point decrease in the rate of severe disability had heavily bombed districts experienced a level of bombing equivalent to low bombed district. ${ }^{15}$ Results illustrate the higher relative long-term impact of bombing on levels of severe disability compared with overall disability.

To examine whether the impact of bombing varies across age cohorts, we ran regressions of the $\log$ of the district disability rate computed for different age cohorts on the log of bomb

\footnotetext{
${ }^{14} 6.53-(6.53 / 1.25)=1.31$

${ }^{15} 1.67-(1.67 / 1.36)=0.44$
} 
density using the preferred IV specification. ${ }^{16}$ Figure 3 presents the estimated effect of log of bomb density on log of the proportion of people with disability at different ages. There is a clear inverted-U shape relationship between the impact of bombing on disability and age. Highest effects occur for people aged around 40 years, the very group born in the years experiencing the highest density of bombing during the war. However, the impact of bombing on disability continues for a long period of time. People born after the war are still impacted by the bombing, although the effect tends to be smaller than for people born before or during the war.

[Tables III, IV, V \& VI]

[Figure 3]

\section{Mechanisms}

As outlined in the conceptual framework, there are multiple pathways through which bombing can impact on disability in the long-run. In Table VII, we present results on the long-term impact of bombing on several channels as relating to nutritional status (proxied by height), living standards, human capital, and public healthcare infrastructure and services using our preferred IV specification. ${ }^{17}$ As shown in the first column, bombing had a negative effect on height in 2001-02. A $10 \%$ increase in bombing leads on average to a 0.035 centimeter reduction in height. The average effect is small but significant at the $1 \%$

\footnotetext{
${ }^{16}$ Since the number of people in each age cohort above 75 is small, we group people above 75 years old into one group.

${ }^{17}$ The first-stage regression at the provincial level is presented in Table A.II.
} 
level. For heavily bombed districts the effect is much larger. Districts in the top quintile experienced a bombing intensity $406 \%$ greater than districts in the bottom quintile. This translates into an average 1.42 centimeter $(406 \times 0.0035)$ reduction in height for people living in a high- versus low-bombed district. Similarly, we find a significant negative effect of bombing on average years of schooling completed for persons 22 years of age and above in the year 2009 (column 4). A $10 \%$ increase in bombing leads on average to a 0.01 year reduction in schooling. This equates to an average 0.41 year $(406 \times 0.001)$ reduction in schooling for people living in a high versus low-bombed district. As shown in columns 2-3 and 5-7, war time bombing had no discernible impact on per capita consumption, the rate of poverty, the number of hospitals, patient beds, and doctors in 2009.

[Table VII]

\section{Discussion}

Overall, our results contribute to the emerging literature on the long-lasting impacts of war on health, measured for the first time through questions from an internationally tested and comparable disability questionnaire. Contrary to an earlier study on the long-run economic impact of the bombing in Vietnam (Miguel \& Roland, 2011), we find a positive effect on non-economic outcomes as measured by disability. As expected, we find a relatively larger effect on severe disability prevalence and among persons born before or during the conflict. Effects decline with age for cohorts born before the war, which may reflect excess mortality in these age groups compared to younger ones. We also find significant, albeit smaller, disability effects among persons born after the cessation of bombing which may be 
explained by any number of indirect mechanisms and continued exposure to UXO, landmines and sprayed chemicals that were correlated with the level of bombing. Our results are consistent with findings relating to long-term effects of bombing on mental health outcomes in Vietnam (Singhal, forthcoming), as well as studies which find an association between war exposure and a range of health outcomes among Vietnamese people born before and after the end of the war (Le et al., 1990; Le \& Johansson, 2001; Ngo et al., 2006; Pham et al., 2013).

It is difficult to disentangle the pathways from bombing to long-run disability in the absence of detailed data in the post-conflict period. We examine the long-term impact of bombing on several common channels as identified in our conceptual framework. Consistent with Miguel \& Roland (2011), we find no significant effects of bombing on long-term poverty rates and consumption per capita. However, consistent with Singhal (2018), we do find a negative long-term effect of bombing on height which is a strong proxy for socioeconomic conditions and nutrition in utero and early childhood (Case \& Paxson, 2010; Strauss \& Thomas, 2008). Poverty and a lack of essential dietary nutrients (such as iodine or folic acid) lead to the onset of a range of health conditions associated with disability (World Health Organization \& World Bank, 2011). Consequently, adverse conditions created or compounded by the war likely contributed to the future ill-health and disability of Vietnamese people. As shown in Appendix Table A.III, we observe larger long-term effects of bombing on height among individuals born before the end of the war versus those born after consistent with patterns on disability (Appendix Table A.I). Effects among those alive during the war may be explained by the substantial threats to economic 
resources, food supply and production. The early post-war reunification period was characterized by widespread food shortages and economic difficulty that may have impacted on cohorts born in areas affected by the war differentially e.g. through the reduction of arable land due to UXO and landmine contamination (Tran, Le \& Husum, 2012). Our results add to a growing empirical literature on the negative impact of conflict on early living conditions and nutrition as a pathway to poor long-term health status (Akresh, Lucchetti \& Thirumurthy, 2012; Bundervoet, Verwimp \& Akresh, 2009; Grimard \& Laszlo, 2014; Minoiu \& Shemyakina, 2014).

We find a negative effect of bombing density on long-run human capital attainment as measured by years of schooling. As shown in Appendix Table A.III, the effect is contained to people born before the end of the war with no significant effect observed for people born after 1975. The result suggests that human capital attainment as an important input to health production is a possible median through which bombing influenced disability over the long term in Vietnam. Our result is consistent with Dell \& Querubin (2018) who find that bombing reduced access to primary school education in hamlets during the war time and is inconsistent with Miguel \& Roland (2011) who find no impact of bombing on long-term literacy rates. More broadly, the result is consistent with other contexts where exposure to conflict is associated with depletion in human capital (Akbulut-Yuksel, 2014; Inchino \& Winter-Ebmer, 2004).

We do not find any discernible long-run impact of bombing on measures of public health infrastructure and services. Similar to the economic story, this suggests that public 
resources may have been equalized across provinces with varying exposure to the war such that the impacts of war on the public health system have disappeared over time. There exists no apparent pathway from healthcare destruction or deterioration to disability over the long term at least. However, as previously discussed, the public health care system deteriorated significantly in the post-reunification period which could hasten the sequela of injuries and health conditions into long-term impairments and disability. Unfortunately, there exists no data on provincial level rehabilitation services. However, disability specific health care services, including rehabilitation, and assistive devices were likely to have been very limited in the post-war period which remain in short supply today (Palmer et al. 2015). This all points to an enduring effect of war-related injuries and impairments on disability.

We do not have access to complete data on UXO, landmines and herbicides so cannot test these mechanisms. However, there exists an obvious relationship with our ordnance measure and $\mathrm{UXO}$, and the planting of landmines and spraying of herbicides is likely to be correlated with the density of bombing in the central and the southern regions. To this extent, our bombing measure will pick up long-term effects on disability associated with exposure to these weapons. According to the Vietnam National Mine Action Centre ${ }^{18}$, since 1975 some 40,000 people have lost their lives and 60,000 persons have been injured due to UXO and mines (VOV, 2016). One-fifth of the injuries derive from six central region provinces where bombing was most concentrated. In Quang Tri province, the heaviest bombed province, the vast majority of injuries stemmed from cluster bombs dropped from

\footnotetext{
${ }^{18}$ http://www.vnmac.gov.vn/en.
} 
aircraft and other ordnance with less than 5\% from landmines (Tran, Le \& Husum, 2012). Our bombing measure may therefore capture the majority of disabling effects associated with exposure to UXO and landmines. To the extent that bombing and spraying patterns differed, further research is required to better establish the long-term population health effects associated with military herbicide exposure.

Our results taken together with those of Miguel \& Roland (2011) suggest that post-war economic recovery patterns may be different from human capital patterns, as measured through disability prevalence, which is consistent with findings from post-war Germany (Akbulut-Yuksel, 2017; Akbulut-Yuksel, 2014). The overall magnitude of the effect of bombing on the long-term disability rate among the Vietnamese population is small though statistically significant. However, there exists large variation across districts reflecting variation in bombing intensity; a heavily bombed district has $25 \%$ more people with disabilities and $36 \%$ more people with severe disabilities due to experiencing a high rather than low bombing intensity during the war. Given that millions of people died during the war and in the four decades since, our findings are surprising and appear to reflect what may have in earlier years been higher rates of disability in heavily bombed areas. In addition, our disability measure is unable to capture a range of mental health conditions commonly associated with warfare exposure, such as depression, anxiety and posttraumatic stress disorder (Do \& Iyer, 2012). We offer a partial and long-term estimate of the effect of war on health for the entire population of Vietnam, which is new in the literature. 


\section{Conclusion}

Vietnam bore the brunt of the most intense and sustained aerial bombing campaign in military history. In this article, we examine the long-term effects on health as measured by an internationally standardized measure of disability. This article shows a significant link between wartime bombing and district level disability prevalence approximately forty years after the war. Highest effects are observed for severe disability and for persons aged around 40 years who were born in the years experiencing the highest density of bombing. Smaller yet significant effects are found for persons born after the war. Disentangling the pathways to long-term disability effects is complex. Our results combined with a review of the theory and historical literature suggest that the likely pathway is through direct exposure to the bombing and other correlated ordnance and weapons including UXO, landmines and dioxin as well as through indirect mechanisms relating to poor nutritional environment, human capital depletion and low quality public healthcare. Taken together with the earlier work of Miguel \& Roland (2011) and Singhal (2018), our findings suggest that wars inflict costs on the health of human populations that last longer than those relating to economic growth and welfare. These findings from Vietnam underpin the importance of expediating the process of cleaning up the consequences of war, and in ensuring food security and adequate health and rehabilitation services for people in conflict-affected zones. The toll of warfare is often assessed in terms of the number of people killed. However, the long-term consequence of warfare on disability is significant and, as this article suggests, deserves closer attention. 
The appendices, dataset, codebook and do-files for the empirical analysis in this article can be found at http://www.prio.org/jpr/datasets.

We gratefully acknowledge comments from the editor Gudrun $\varnothing$ stby and three anonymous reviewers, Dennis Petrie, participants of the IRDES-Dauphine Workshop on Applied Health Economics and Policy Evaluation (Paris, France), the GREThA International Conference on Economic Development (Bordeaux, France), and the Australian Health Economics Society Conference (Hobart, Australia).

\section{References}

Akbulut-Yuksel, Melvude (2017) War during childhood: The long run effects of warfare on health. Journal of Health Economics 53: 117-130.

Akbulut-Yuksel, Mevlude (2014) Children of War: The Long-Run Effects of Large-Scale Physical Destruction and Warfare on Children. Journal of Human Resources 49(3): 634-662.

Akresh, Richard; Leonardo Lucchetti \& Harsha Thirumurthy (2012) Wars and child health: Evidence from the Eritrean-Ethiopian conflict. Journal of Development Economics 99: 330340. 
Almond, Douglas \& Janet Currie (2011) Human capital development before age five. In: O Ashenfelter \& D E Card (eds) Handbook of Labour Economics, vol. 4B. Elsevier (13151486).

Angrist, Joshua D; Guido W Imbens \& Donald B Rubin (1996) Indentification of causal effects using instrumental variables. Journal of the American Statistical Association 91(434): 444-455.

Angrist, Joshua D \& Jorn-Steffan Pischke (2008) Mostly Harmless Econometrics: An Empiricist's Companion. Princeton, New Jersey: Princeton University Press.

Appy, Christian G (2015) American reckoning: The Vietnam War and our national identity. New York: Penguin Publishing Group.

Barker, David James Purslove (1992) Fetal and infant origins of later life disease. British Medical Journal.

Brakman, Steven; Harry Garretsen \& Marc Schramm (2004) The strategic bombing of German cities during World War II and its impact on city growth. Journal of Economic Geography 4(2): 201-218.

Bundervoet, Tom; Philip Verwimp \& Richard Akresh (2009) Health and civil war in rural Burundi. Journal of Human Resources 44(2): 536-563.

Cameron, Colin; Jonah B Gelbach \& Douglas L Miller (2011) Robust inference with multiway clustering. Journal of Business and Economic Statistics 29(2): 238-249.

Case, Anne \& Christina Paxson (2010) Causes and consequences of early life health. Demography 47(S65-S85).

Clodfelter, Michael (1995) Vietnam in Military Statistics: A History of the Indochina Wars, 1772-1991. Jefferson, NC: McFarland.

Cragg, John G \& Stephen G Donald (1993) Testing identifiability and specification in instrumental variable models. Econometric Theory 9: 222-240. 
Davis, Donald R \& David E Weinstein (2002) Bones, bombs and break points: the geography of economic activity. The American Economic Review 92(5): 1269-1289.

Dell, Melissa \& Pablo Querubin (2018) Nation building through foreign intervention: Evidence from discontinuities in military strategy. The Quarterly Journal of Economics 133(2): 701-764.

Do, Quy-Toan (2009) Agent Orange and the Prevalence of Cancer among the Vietnamese Population 30 Years after the End of the Vietnam War. Washington DC: The World Bank.

Do, Quy-Toan \& Lakshmi Iyer (2012) Mental health in the aftermath of conflict. In: Michelle R. Garfinkel \& Stergios Skaperdas (eds) The Oxford Handbook of the Economics of Peace and Conflict. Oxford: Oxford University Press.

Ensor, Tim \& Pham Bich San (1996) Access and Payment for Health Care: The Poor of Northern Vietnam. International Journal of Health Planning and Management 11: 69-83.

Ghobarah, Hazem Adam; Paul Huth \& Bruce Russert (2003) Civil wars kills and maim people long after the shooting stops. The American Journal of Political Science 97(2): 189202.

Grimard, F \& S Laszlo (2014) Long-Term Effects of Civil Conflict on Women's Health Outcomes in Peru. World Development 54: 139-155.

Heckman, James J; Robert J Lalonde \& Jeffrey A Smith (1999) The economics and econometrics of active labor market programs. In: Orley Ashenfelter \& David Card (eds) Handbook of Labour Econoimcs. Amsterdam: Elsevier Science.

Hirschman, Charles; Samuel Preston \& Loi Manh Vu (1995) Vietnamese casualities during the American War: A new estimate. Population and Development Review 21(4): 783-812.

Hoang, Ha (2018) Ký ức buồn của những người suýt bỏ mạng, vướng lao lý vì mưu sinh bằng 'nghề' đào bomb. (The sad memories of those who nearly lost their lives or went to jail due to the bombing mining 'industry'). Doi Song Phat Luat, 18/12/2018. 4. 
Inchino, Andrea \& Rudolf Winter-Ebmer (2004) The long-run education cost of World War II. Journal of Labour Economics 22(1): 57-86.

Institute of Medicine (2014) Veterans and Agent Orange. Washington D.C.: The National Academies Press.

Kalyvas, Stathis N \& Matthew Adam Kocher (2009) The Dynamics of Violence in Vietnam: An Analysis of the Hamlet Evaluation System. Journal of Peace Research 46(3): 335-355.

Kleibergen, Frank \& Richard Paap (2006) Generalized reduced rank tests using the singular value decomposition. Journal of Econometrics 1333: 97-126.

Kocher, Matthew Adam; Thomas B Pepinsky \& Stathis N Kalyvas (2011) Aerial bombing and insurgency in the Vietnam War. American Journal of Political Science 55(2): 201-218.

Lanjouw, Peter; Marleen Marra \& Cuong Nguyen (2017) Vietnam's Evolving Poverty Index Map: Patterns and Implications for Policy. Social Indicators Research 133(1): 93-118.

Le, Dai Cao, Phuong Ngoc Thi Nguyen, Thom Hong Le, Thuy Thi Tran, Van Tu Thi Nguyen, Cam Hong Le, Chi Kim Thi Huynh \& Thuy Bich Le (1990) A comparison of infant mortality rates between two Vietnamese villages sprayed by defoliants in wartime and one unsprayed village. Chemosphere 20(7-9): 1005-1012.

Le, Tuyet Nham Thi \& Annika Johansson (2001) Impact of chemical warfare with Agent Orange on women's reproductive lives in Vietnam: A pilot study. Reproductive Health Matters 9(18): 156-164.

Madans, Jennifer H; Mitchell E Loeb \& Barbara M Altman (2010) Measuring disability and monitoring the UN Convention on the Rights of Persons with Disabilities: the work of the Washington Group on Disability Statistics. BMC Public Health 11(S4): 1-8.

Madans, Jennifer; Mitchell Loeb \& Arne H Eide (2017) Measuring disability and inclusion in relation ot the 2030 agenda on sustainable development. Disability and the Global South 4(1): 1164-1179. 
Miguel, Edward \& Gerard Roland (2011) The long-run impact of bombing Vietnam. Journal of Development Economics 96: 1-15.

Minoiu, Camelia \& Olga N Shemyakina (2014) Armed conflict, household victimization, and child health in Cote d'Ivoire. Journal of Development Economics (237-255).

Mont, Daniel (2007) Measuring health and disability. The Lancet 369(9573): 1658-1663.

Ngo, Anh D, Richard Taylor, Christine L Roberts \& Tuan V Nguyen (2006) Association between Agent Orange and birth defects: systematic review and meta-analysis. International Journal of Epidemiology 35: 1220-1230.

Obermeyer, Ziad; Christopher J L Murray \& Emmanuela Gakidou (2008) Fifty Years of Violent War Deaths from Vietnam to Bosnia: Analysis of Data from the World Health Survey Programme. British Medical Journal 336: 1482-1486.

Palmer, Michael G (2007) The Case of Agent Orange. Contemporary Southeast Asia 29(1): 172-195.

Pham, Tai The, Muneko Nishijo, Anh Nguyet Thi Nguyen, Shoko Maruzeni, Hideaki Nakagawa, Luong Van Hoang, Anh Hai Tran, Ryumon Honda, Teruhiko Kido \& Hisao Nishijo (2013) Dioxin exposure in breast milk and infant neurodevelopment in Vietnam. Occup Environ Med 70: 656-662.

Savitz, David A, Thang Minh Nguyen, Ingrid E Swenson \& Erika M Stone (1993) Vietnamese infant and childhood mortality in relation to the Vietnam War. American Journal of Public Health 83(8): 1134-1138.

Segall, M, G Tipping, H Lucas, T V Dung, N T Tam, D X Vinh \& D L Huong (2002) Economic transition should come with a health warning: the case of Vietnam. Journal of Epidemiology Community Health 56(7): 497-505.

Singhal, Saurabh (forthcoming) Early life shocks and mental health: The long-term effect of war in Vietnam. Journal of Development Economics doi.org/10.1016/j.jdeveco.2018.06.002. 
Staiger, Douglas \& James H Stock (1997) Instrumental variables regression with weak instruments. Econometrica 65(3): 557-586.

Stellman, Jeanne Mager, Steven D Stellman, Richard Christian, Tracy Weber \& Carrie Tomasallo (2003) The extent and patterns of usage of Agent Orange and other herbicides in Vietnam. Nature 422: 681-687.

Strauss, John \& Duncan Thomas (2008) Health over the life course. In: T Paul Schultz \& John Strauss (eds) Handbook of Development Economics, vol. 4. Amsterdam: Elsevier/North Holland (3374-3465).

Teerawichitchainan, Bussarawan \& Kim Korinek (2012) The long-term impact of war on health and wellbeing in Northern Vietnam: Some glimpes from a recent survey. Social Science and Medicine 74: 1995-2004.

Thayer, Thomas C (1975) A systems analysis view of the Vietnam War: 1965-1972. Virginia, U.S.: Defense Technical Information Centre.

Tirman, John (2011) The deaths of others: The fate of civilians in America's wars. Oxford: Oxford University Press.

Tran, Phung Kim; Viet Le \& Hans Husum (2012) The legacy of war: An epidemiological study of cluster weapon and land mine accidents in Quang Tri province, Vietnam. Southeast Asian Journal of Tropical Medicine and Public Health 43(4): 1035-1041.

Tuoitre (2018) Gần 19\% diện tích cả nước ô nhiễm bom mìn, vật nổ. (Near 19\% of land in Vietnam is polluted by bombs and mines). Tuoitre Online.

Ugalde, Antonio; Patricia L Richards \& Anthony Zwi (1999) Health Consequences of War and Political Violence. In: Lester Kurtz (ed.) Encyclopedia of Violence, Peace and Conflict, vol. 2. San Diego, CA: Academic Press (103-121).

VOV (2016) Over 100,000 people wounded by bombs and mines left behind after the war. Voice of Vietnam, 31 March. 
Washington Group on Disability Statistics (2017) The Washington Group Short Set on Functioning (WG-SS).

World Bank (2011) World Development Report 2011 - Conflict, Security and Development. Washington D.C.: The World Bank.

World Health Organization (2001) International Classification of Functioning, Disability and Health (ICF). Geneva, Switzerland: World Health Organization.

World Health Organization \& World Bank (2011) World Disability Report. Geneva: World Health Organization.

\section{Biographical Statements}

MICHAEL PALMER, b. 1976, PhD in Health Economics (Australian National University, 2011); Senior Lecturer in Economics, University of Western Australia (2018-).

CUONG VIET NGUYEN, b. 1976, PhD in Development Economics (Wageningen University, 2009); Researcher in Economics, National Economics University (1998-), and Mekong Development Research Institute (2013-).

SOPHIE MITRA, b. 1970, PhD in Economics (Université Paris 1 Panthéon-Sorbonne, 2001). Professor of Economics and Co-Director of Disability Studies, Fordham University, New York (2017-). 
DANIEL MONT, b. 1961, PhD in Economics (University of Wisconsin-Madison, 1989); Co-President, Center for Inclusive Policy (2016-) and Honorary Seniore Research Fellow, University College London (2014-).

NORA ELLEN GROCE, b. 1952. PhD in Anthropology (Brown University 1983). Director and Chair, University College London (UCL) Disability Research Center, London (2008-).

\section{Tables and figures}

Table I. District-level disability prevalence 


\begin{tabular}{|c|c|c|c|c|c|c|}
\hline & \multicolumn{5}{|c|}{ Districts by quintiles of bombs, missiles, rockets per $\mathrm{km}^{2}$} & \multirow[b]{2}{*}{ Tota } \\
\hline & Lowest & Near lowest & Middle & Near highest & Highest & \\
\hline \multicolumn{7}{|c|}{ Disability prevalence by functioning domain } \\
\hline Seeing & 5.27 & 5.00 & 4.83 & 4.96 & 5.61 & 5.13 \\
\hline Hearing & 3.50 & 3.09 & 3.09 & 3.04 & 3.47 & 3.24 \\
\hline Walking & 3.94 & 3.60 & 3.63 & 3.55 & 4.09 & 3.76 \\
\hline Remembering & 3.70 & 3.47 & 3.53 & 3.50 & 3.95 & 3.63 \\
\hline Any domain & 6.31 & 5.76 & 5.85 & 5.72 & 6.53 & 6.03 \\
\hline \multicolumn{7}{|c|}{ Severe disability prevalence by functioning domain } \\
\hline Seeing & 0.65 & 0.59 & 0.61 & 0.63 & 0.72 & 0.64 \\
\hline Hearing & 0.66 & 0.60 & 0.62 & 0.61 & 0.70 & 0.64 \\
\hline Walking & 0.90 & 0.85 & 0.88 & 0.89 & 1.03 & 0.91 \\
\hline Remembering & 0.79 & 0.78 & 0.81 & 0.81 & 0.94 & 0.83 \\
\hline Any domain & 1.47 & 1.40 & 1.45 & 1.45 & 1.67 & 1.49 \\
\hline
\end{tabular}


Table II. The district-level prevalence rate of disability for people born before and since 1976

\begin{tabular}{|c|c|c|c|c|c|c|}
\hline & \multicolumn{5}{|c|}{ Districts by quintiles of bombs, missiles, rockets per $\mathrm{km}^{2}$} & \multirow[b]{2}{*}{ Total } \\
\hline & Lowest & Near lowest & Middle & Near highest & Highest & \\
\hline \multicolumn{7}{|l|}{ People born before 1976} \\
\hline Disability in any domain & 12.59 & 11.11 & 11.53 & 11.36 & 12.47 & 11.81 \\
\hline Severe disability in any domain & 2.71 & 2.44 & 2.57 & 2.58 & 2.88 & 2.63 \\
\hline \multicolumn{7}{|l|}{ People born since 1976} \\
\hline Disability in any domain & 1.55 & 1.33 & 1.45 & 1.39 & 1.51 & 1.44 \\
\hline Severe disability in any domain & 0.53 & 0.53 & 0.57 & 0.56 & 0.64 & 0.57 \\
\hline
\end{tabular}


Table III. OLS regression of disability prevalence rates

\begin{tabular}{|l|c|c|c|c|c|}
\hline Explanatory variables & Seeing & Hearing & Walking & Remembering & Any domain \\
\hline Log of bombs, missiles, rockets per km2 & $0.0170^{\dagger}$ & $0.0124^{\dagger}$ & $0.0129^{\dagger}$ & $0.0223^{* *}$ & $0.0149^{*}$ \\
\hline Log of area of district & $(0.0088)$ & $(0.0064)$ & $(0.0068)$ & $(0.0071)$ & $(0.0060)$ \\
\hline & -0.0297 & $-0.0700^{* *}$ & -0.0372 & $-0.0476^{\dagger}$ & -0.0344 \\
\hline Log of mean elevation & $(0.0323)$ & $(0.0261)$ & $(0.0276)$ & $(0.0271)$ & $(0.0239)$ \\
\hline & $-0.0237^{*}$ & -0.0017 & $-0.0326^{* *}$ & -0.0159 & -0.0141 \\
\hline Northern (yes=1, no=0) & $(0.0116)$ & $(0.0098)$ & $(0.0097)$ & $(0.0103)$ & $(0.0089)$ \\
\hline & $0.2355^{* *}$ & $0.4126 * *$ & $0.3605^{* *}$ & $0.3548^{* *}$ & $0.3333^{* *}$ \\
\hline Capital district of province (yes=1, no=0) & $(0.0393)$ & $(0.0335)$ & $(0.0331)$ & $(0.0357)$ & $(0.0302)$ \\
\hline & -0.0609 & 0.0123 & 0.0241 & 0.0446 & 0.0347 \\
\hline Log of distance to closest cities: Hanoi, Da Nang, HCMC & $(0.0780)$ & $(0.0536)$ & $(0.0544)$ & $(0.0559)$ & $(0.0486)$ \\
\hline & $0.0597 *$ & $0.0626 * *$ & $0.0599 * *$ & $0.0494 *$ & $0.0482^{* *}$ \\
\hline Share of urban population & $(0.0262)$ & $(0.0202)$ & $(0.0219)$ & $(0.0206)$ & $(0.0184)$ \\
\hline & $-0.2972 *$ & $-0.5798^{* *}$ & $-0.4377 * *$ & $-0.5326 * *$ & $-0.4581^{* *}$ \\
\hline Constant & $(0.1195)$ & $(0.0893)$ & $(0.0831)$ & $(0.0882)$ & $(0.0777)$ \\
\hline Observations & $-3.4176^{* *}$ & $-3.6198 * *$ & $-3.7433^{* *}$ & $-3.6151^{* *}$ & $1.4648^{* *}$ \\
\hline R-squared & $(0.2173)$ & $(0.1943)$ & $(0.1932)$ & $(0.1932)$ & $(0.1726)$ \\
\hline
\end{tabular}

${ }^{* *} p<0.01, * p<0.05,{ }^{\dagger} p<0.1$. Robust clustered standard errors in parentheses. 
Table IV. OLS regression of severe disability prevalence rates

\begin{tabular}{|l|c|c|c|c|c|}
\hline & Severe & Severe & Severe & Severe & Severe \\
\hline Explanatory variables & Seeing & Hearing & Walking & Remembering & Any domain \\
\hline Log of bombs, missiles, rockets per $\mathrm{km}^{2}$ & $0.0319^{* *}$ & $0.0261^{* *}$ & $0.0293^{* *}$ & $0.0390^{* *}$ & $0.0301^{* *}$ \\
\hline Log of area of district & $(0.0093)$ & $(0.0077)$ & $(0.0079)$ & $(0.0076)$ & -0.0069 \\
\hline & -0.0375 & $-0.0567^{\dagger}$ & -0.0417 & $-0.0635^{*}$ & $-0.0471^{\dagger}$ \\
\hline Log of mean elevation & $(0.0356)$ & $(0.0306)$ & $(0.0313)$ & $(0.0303)$ & $(0.0275)$ \\
\hline & -0.0195 & -0.0041 & $-0.0358^{* *}$ & -0.018 & $-0.0181^{\dagger}$ \\
\hline Northern (yes=1, no=0) & $(0.0127)$ & $(0.0114)$ & $(0.0110)$ & $(0.0112)$ & $(0.0101)$ \\
\hline & $0.3847^{* *}$ & $0.4599^{* *}$ & $0.3854^{* *}$ & $0.4256^{* *}$ & $0.3849 * *$ \\
\hline Capital district of province (yes=1, no=0) & $(0.0425)$ & $(0.0384)$ & $(0.0365)$ & $(0.0371)$ & $(0.0341)$ \\
\hline & -0.1035 & -0.0164 & 0.0206 & 0.0266 & 0.0368 \\
\hline Log of distance to closest cities: Hanoi, Da Nang, HCMC & $(0.0806)$ & $(0.0642)$ & $(0.0611)$ & $(0.0607)$ & $(0.0556)$ \\
\hline & $0.0553^{*}$ & $0.0455^{\dagger}$ & $0.0451^{\dagger}$ & 0.0299 & $0.0378^{\dagger}$ \\
\hline Share of urban population & $(0.0281)$ & $(0.0242)$ & $(0.0245)$ & $(0.0220)$ & $(0.0209)$ \\
\hline & $-0.4266^{* *}$ & $-0.5542^{* *}$ & $-0.3893^{* *}$ & $-0.4990^{* *}$ & $-0.4488^{* *}$ \\
\hline Constant & $(0.1213)$ & $(0.1014)$ & $(0.0929)$ & $(0.0906)$ & $(0.0840)$ \\
\hline & $-0.9243^{* *}$ & $-0.7264 * *$ & $-0.5511^{*}$ & $-0.4153^{*}$ & 0.0918 \\
\hline Observations & $(0.2459)$ & $(0.2184)$ & $(0.2139)$ & $(0.2112)$ & $(0.1962)$ \\
\hline R-squared & 612 & 612 & 612 & 612 & 612 \\
\hline
\end{tabular}

${ }^{* *} p<0.01, * p<0.05,{ }^{\dagger} p<0.1$. Robust clustered standard errors in parentheses. 
Table V. IV regression of disability prevalence rates

\begin{tabular}{|l|c|c|c|c|c|}
\hline Explanatory variables & Seeing & Hearing & Walking & Remembering & Any domain \\
\hline Log of bombs, missiles, rockets per km2 & $0.0500^{* *}$ & $0.0523^{* *}$ & $0.0516^{* *}$ & $0.0800^{* *}$ & $0.0606^{* *}$ \\
\hline & $(0.0131)$ & $(0.0103)$ & $(0.0109)$ & $(0.0119)$ & $(0.0095)$ \\
\hline Log of area of district & -0.0307 & $-0.0711^{* *}$ & -0.0383 & $-0.0493^{\dagger}$ & -0.0357 \\
\hline & $(0.0322)$ & $(0.0266)$ & $(0.0280)$ & $(0.0286)$ & $(0.0248)$ \\
\hline Log of mean elevation & -0.0161 & 0.0075 & $-0.0236^{*}$ & -0.0026 & -0.0035 \\
\hline & $(0.0117)$ & $(0.0100)$ & $(0.0099)$ & $(0.0108)$ & $(0.0091)$ \\
\hline Northern (yes=1, no=0) & $0.2522^{* *}$ & $0.4328^{* *}$ & $0.3801^{* *}$ & $0.3841^{* *}$ & $0.3565^{* *}$ \\
\hline & $(0.0394)$ & $(0.0340)$ & $(0.0340)$ & $(0.0371)$ & $(0.0312)$ \\
\hline Capital district of province (yes=1, no=0) & -0.066 & 0.0062 & 0.0181 & 0.0357 & 0.0276 \\
\hline & $(0.0796)$ & $(0.0576)$ & $(0.0586)$ & $(0.0630)$ & $(0.0543)$ \\
\hline Log of distance to closest cities: Hanoi, Da Nang, HCMC & $0.0555^{*}$ & $0.0575^{* *}$ & $0.0550^{*}$ & $0.0421^{\dagger}$ & $0.0424^{*}$ \\
\hline & $(0.0256)$ & $(0.0204)$ & $(0.0221)$ & $(0.0216)$ & $(0.0191)$ \\
\hline Share of urban population & $-0.3170^{* *}$ & $-0.6038^{* *}$ & $-0.4610^{* *}$ & $-0.5674^{* *}$ & $-0.4856^{* *}$ \\
\hline & $(0.1185)$ & $(0.0904)$ & $(0.0845)$ & $(0.0920)$ & $(0.0805)$ \\
\hline Constant & $-3.4351^{* *}$ & $-3.6409 * *$ & $-3.7637^{* *}$ & $-3.6456^{* *}$ & $1.4407^{* *}$ \\
\hline & $(0.2202)$ & $(0.2009)$ & $(0.2000)$ & $(0.2060)$ & $(0.1818)$ \\
\hline Observations & 612 & 612 & 612 & 612 & 612 \\
\hline R-squared & 0.099 & 0.357 & 0.254 & 0.214 & 0.260 \\
\hline
\end{tabular}

$* * p<0.01, * p<0.05,{ }^{\dagger} p<0.1$. Robust clustered standard errors in parentheses. 
Table VI. IV regression of severe disability prevalence rates

\begin{tabular}{|c|c|c|c|c|c|}
\hline & Severe & Severe & Severe & Severe & Severe \\
\hline Explanatory variables & Seeing & Hearing & Walking & Remembering & Any domain \\
\hline \multirow[t]{2}{*}{ Log of bombs, missiles, rockets per $\mathrm{km}^{2}$} & $0.0904 * *$ & $0.0791 * *$ & $0.0784 * *$ & $0.1016^{* *}$ & $0.0881 * *$ \\
\hline & $(0.0149)$ & $(0.0126)$ & $(0.0139)$ & $(0.0125)$ & $(0.0117)$ \\
\hline \multirow[t]{2}{*}{ Log of area of district } & -0.0392 & $-0.0582^{\dagger}$ & -0.0431 & $-0.0653 *$ & $-0.0488^{\dagger}$ \\
\hline & $(0.0361)$ & $(0.0315)$ & $(0.0322)$ & $(0.0317)$ & $(0.0290)$ \\
\hline \multirow[t]{2}{*}{ Log of mean elevation } & -0.006 & 0.0081 & $-0.0245^{*}$ & -0.0035 & -0.0047 \\
\hline & $(0.0130)$ & $(0.0116)$ & $(0.0116)$ & $(0.0116)$ & $(0.0105)$ \\
\hline \multirow[t]{2}{*}{ Northern $($ yes $=1$, no $=0$ ) } & $0.4143 * *$ & $0.4868 * *$ & $0.4103 * *$ & $0.4574 * *$ & $0.4143 * *$ \\
\hline & $(0.0439)$ & $(0.0400)$ & $(0.0382)$ & $(0.0393)$ & $(0.0363)$ \\
\hline \multirow[t]{2}{*}{ Capital district of province (yes $=1$, no $=0$ ) } & -0.1125 & -0.0245 & 0.013 & 0.0169 & 0.0279 \\
\hline & $(0.0866)$ & $(0.0701)$ & $(0.0672)$ & $(0.0690)$ & $(0.0642)$ \\
\hline \multirow[t]{2}{*}{ Log of distance to closest cities: Hanoi, Da Nang, HCMC } & $0.0478^{\dagger}$ & 0.0388 & 0.0388 & 0.0219 & 0.0304 \\
\hline & $(0.0284)$ & $(0.0246)$ & $(0.0249)$ & $(0.0231)$ & $(0.0218)$ \\
\hline \multirow[t]{2}{*}{ Share of urban population } & $-0.4618^{* *}$ & $-0.5861 * *$ & $-0.4189 * *$ & $-0.5367 * *$ & $-0.4838 * *$ \\
\hline & $(0.1242)$ & $(0.1046)$ & $(0.0966)$ & $(0.0955)$ & $(0.0890)$ \\
\hline \multirow[t]{2}{*}{ Constant } & $-0.9553 * *$ & $-0.7544 * *$ & $-0.5770 *$ & $-0.4484^{*}$ & 0.0611 \\
\hline & $(0.2548)$ & $(0.2289)$ & $(0.2241)$ & $(0.2247)$ & $(0.2097)$ \\
\hline Observations & 612 & 612 & 612 & 612 & 612 \\
\hline $\mathrm{R}$-squared & 0.159 & 0.287 & 0.197 & 0.226 & 0.219 \\
\hline
\end{tabular}

$* * p<0.01, * p<0.05,{ }^{\dagger} p<0.1$. Robust clustered standard errors in parentheses. 
Table VII. IV regression of other outcomes

\begin{tabular}{|c|c|c|c|c|c|c|c|}
\hline \multirow[b]{3}{*}{ Explanatory variables } & Height & \multirow{3}{*}{$\begin{array}{l}\text { Log of per } \\
\text { capita } \\
\text { expenditure }\end{array}$} & \multirow{3}{*}{$\begin{array}{c}\text { Log of } \\
\text { poverty rate }\end{array}$} & \multirow{3}{*}{$\begin{array}{c}\text { Years of } \\
\text { schooling } \\
\text { completed }\end{array}$} & \multirow{3}{*}{$\begin{array}{c}\text { Log of } \\
\text { hospitals per } \\
\text { one million } \\
\text { people }\end{array}$} & \multirow{3}{*}{$\begin{array}{c}\text { Log of } \\
\text { patient beds } \\
\text { per one } \\
\text { million }\end{array}$} & \multirow{3}{*}{$\begin{array}{c}\text { Log of } \\
\text { doctors per } \\
\text { one million } \\
\text { people }\end{array}$} \\
\hline & & & & & & & \\
\hline & & & & & & & \\
\hline \multirow[t]{2}{*}{ Log of bombs, missiles, rockets per $\mathrm{km}^{2}$} & $-0.3505^{* *}$ & -0.0077 & -0.0051 & $-0.1011 *$ & 0.0123 & 0.0312 & 0.0324 \\
\hline & $(0.056)$ & $(0.0098)$ & $(0.0209)$ & $(0.0485)$ & $(0.0452)$ & $(0.0441)$ & $(0.0596)$ \\
\hline \multirow[t]{2}{*}{$\log$ of area of district } & 0.0380 & $-0.0771 * *$ & $0.2090 * *$ & $-0.5489 * *$ & 0.0786 & 0.0745 & -0.0403 \\
\hline & $(0.086)$ & $(0.0161)$ & $(0.0519)$ & $(0.0955)$ & $(0.0955)$ & $(0.0899)$ & $(0.1026)$ \\
\hline \multirow[t]{2}{*}{ Log of mean elevation } & $-0.4562 * *$ & $-0.0401 * *$ & $0.0917 * *$ & -0.0337 & -0.019 & $-0.0601^{\dagger}$ & -0.0578 \\
\hline & $(0.041)$ & $(0.0068)$ & $(0.0169)$ & $(0.0356)$ & $(0.0283)$ & $(0.0330)$ & $(0.0399)$ \\
\hline \multirow[t]{2}{*}{ Northern $($ yes $=1$, no $=0$ ) } & $-0.5453 * *$ & $-0.0628 * *$ & 0.0035 & $0.9509^{* *}$ & $0.2498^{*}$ & $0.3287^{*}$ & 0.192 \\
\hline & $(0.145)$ & $(0.0208)$ & $(0.0621)$ & $(0.1127)$ & $(0.1204)$ & $(0.1496)$ & $(0.1785)$ \\
\hline \multirow[t]{2}{*}{ Capital district of province $(\mathrm{yes}=1, \mathrm{no}=0$ ) } & $0.3985^{*}$ & $0.1527 * *$ & -0.1867 & $1.0599 * *$ & & & \\
\hline & $(0.190)$ & $(0.0350)$ & $(0.1418)$ & $(0.1782)$ & & & \\
\hline \multirow[t]{2}{*}{ Log of distance to closest cities: Hanoi, Da Nang, or HCMC } & $-0.1699 *$ & $-0.1143 * *$ & $0.4125^{* *}$ & $-0.3929 * *$ & & & \\
\hline & $(0.080)$ & $(0.0135)$ & $(0.0499)$ & $(0.0665)$ & & & \\
\hline \multirow[t]{2}{*}{ Share of urban population } & $0.6996^{* *}$ & $0.3773 * *$ & $-1.2241 * *$ & $0.7245^{* *}$ & $1.2495 * *$ & 1.2455 & $1.4907^{\dagger}$ \\
\hline & $(0.153)$ & $(0.0538)$ & $(0.1884)$ & $(0.2687)$ & $(0.4130)$ & $(0.9808)$ & $(0.8230)$ \\
\hline \multirow[t]{2}{*}{ Age } & $3.1049 * *$ & & & & & & \\
\hline & $(0.014)$ & & & & & & \\
\hline \multirow[t]{2}{*}{$\mathrm{Age}^{2}$} & $-0.0344 * *$ & & & & & & \\
\hline & $(0.000)$ & & & & & & \\
\hline \multirow[t]{2}{*}{ Male $($ male $=1$, female $=0)$} & $6.6990 * *$ & & & & & & \\
\hline & $(0.083)$ & & & & & & \\
\hline \multirow[t]{2}{*}{ Constant } & $97.1858 * *$ & $10.2646^{* *}$ & 0.3979 & $11.1557 * *$ & $1.3678^{\dagger}$ & $6.7613^{* *}$ & $6.2281 * *$ \\
\hline & $(0.442)$ & $(0.1197)$ & $(0.4126)$ & $(0.6336)$ & $(0.7250)$ & $(0.7212)$ & $(0.7761)$ \\
\hline Observations & 137,543 & 612 & 612 & 612 & 63 & 63 & 63 \\
\hline R-squared & 0.726 & 0.734 & 0.731 & 0.543 & 0.144 & 0.242 & 0.274 \\
\hline
\end{tabular}

$* * p<0.01, * p<0.05,{ }^{\dagger} p<0.1$. Robust clustered standard errors in parentheses. 
Figure 1. Log of the bomb density and $\log$ of the percentage of disability

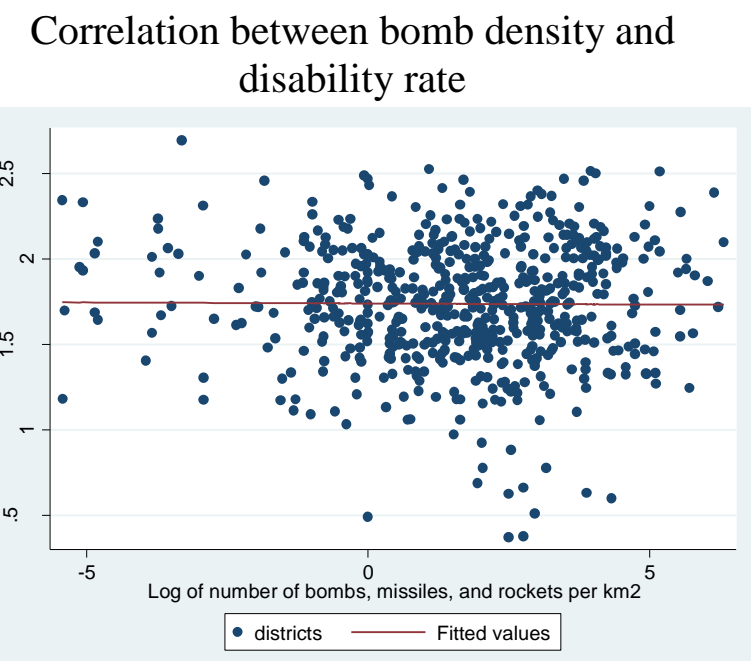

Correlation between bomb density and severe disability rate

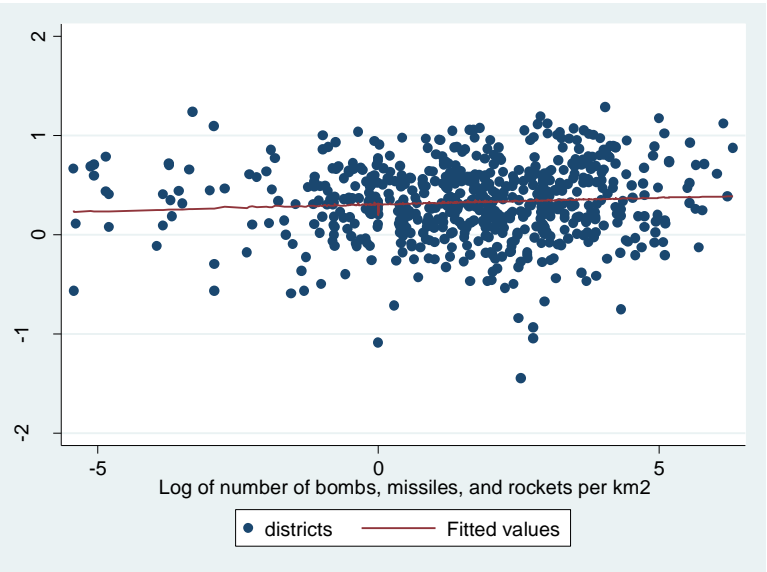


Figure 2. Bomb density and disability rate at the district level

Number of bombs, missiles and rocket per $\mathrm{km}^{2}$

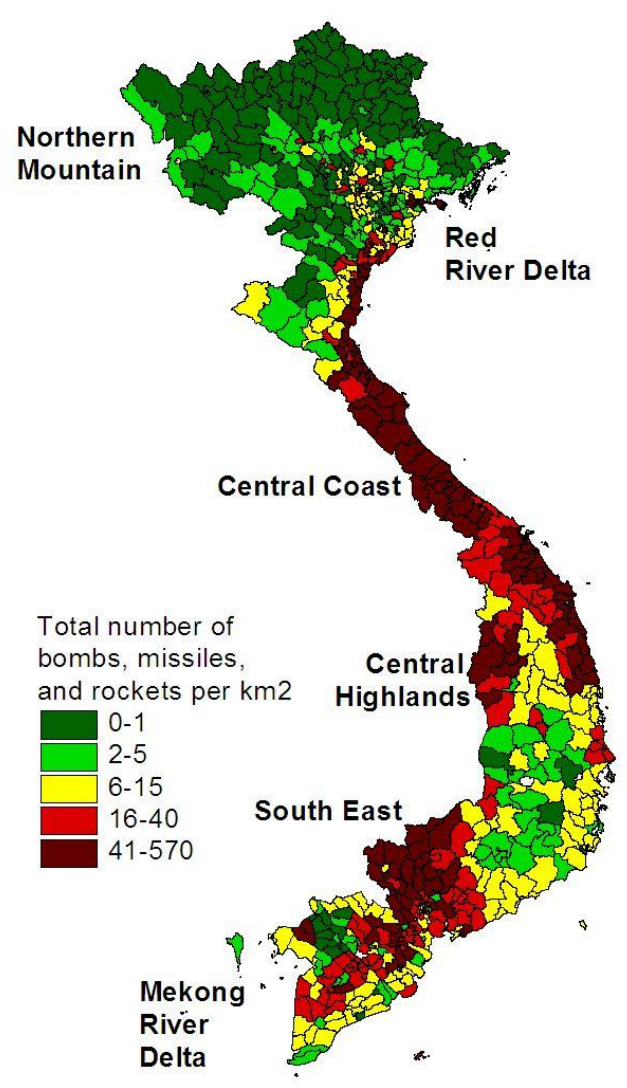

Percentage of people with disability in any domain

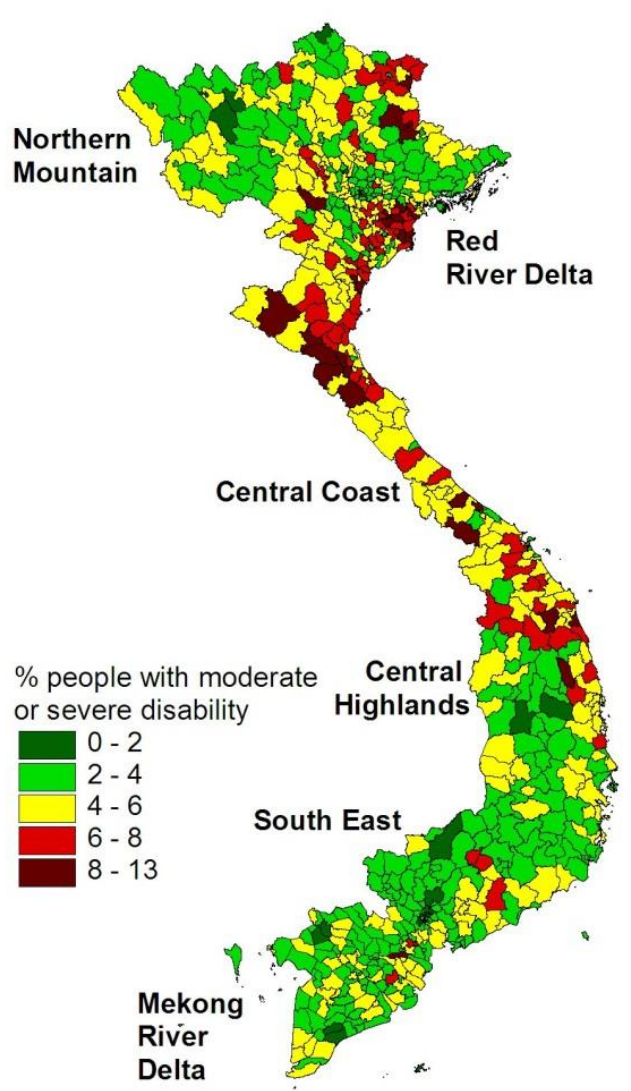

Percentage of people with severe disability in any domain

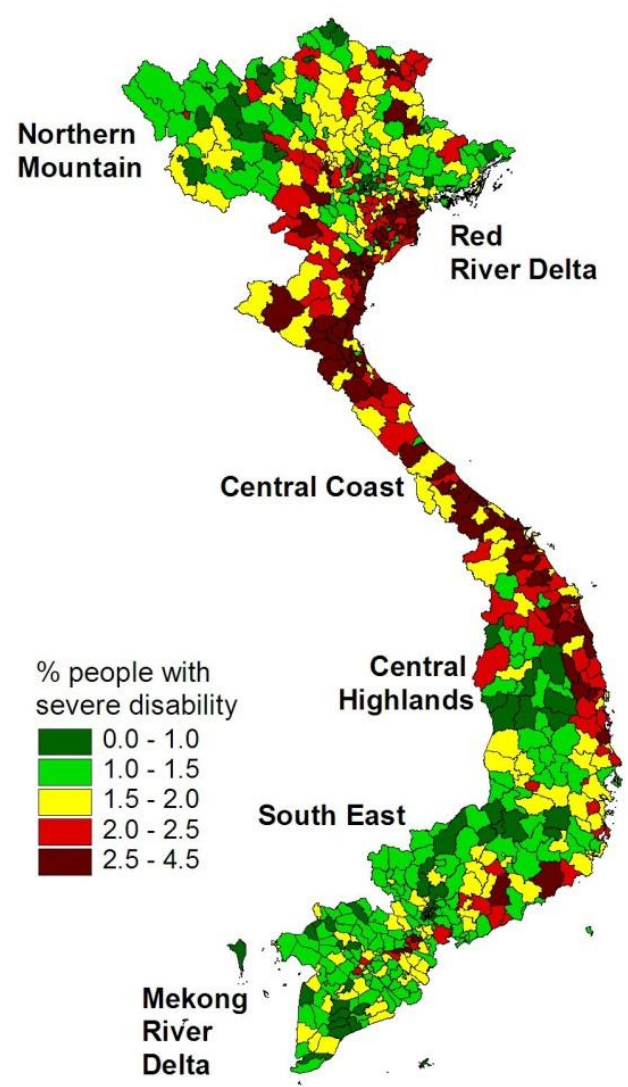


Figure 3. The estimated effect of log of bomb density on log of the proportion of people with disability

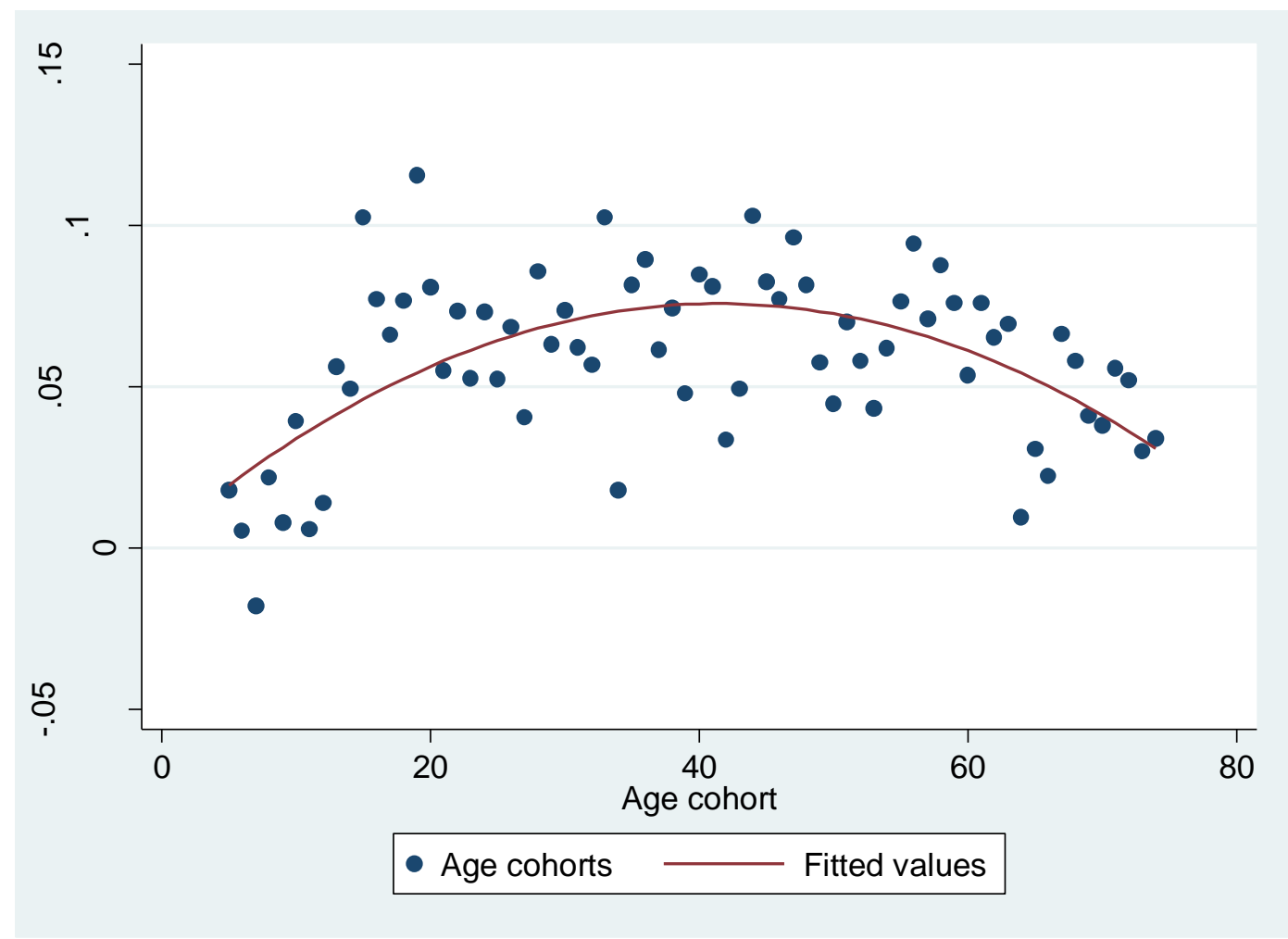


